IRA-International Journal of Management \& Social Sciences

ISSN 2455-2267; Vol.07, Issue 02 (2017)

Pg. no. 250-257

Institute of Research Advances

http://research-advances.org/index.php/RAJMSS

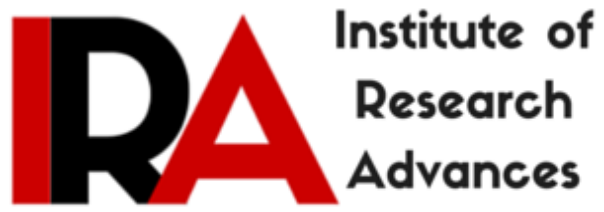

\title{
Perception with Respect to Compensation Structure: A Study of Workmen in Manufacturing Industries in North Karnataka
}

Shashidhar Mahantshetti

Assistant Professor, Angadi Institute of Technology \& Management, India.

Smita M. Chanabasappagol

Assistant Professor, Angadi Institute of Technology \& Management, India.

\section{Rukhsar M. Shaikh}

Student, MBA, Angadi Institute of Technology \& Management, India.

Type of Review: Peer Reviewed.

DOI: http://dx.doi.org/10.21013/jmss.v7.n2.p15

\section{How to cite this paper:}

Mahantshetti, S., Chanabasappagol, S., \& Shaikh, R. (2017). Perception with Respect to

Compensation Structure: A Study of Workmen in Manufacturing Industries in North Karnataka. IRA-International Journal of Management \& Social Sciences (ISSN 2455-2267), 7(2), 250-257. doi:http://dx.doi.org/10.21013/jmss.v7.n2.p15

(C) Institute of Research Advances

\section{(cc) BY-NO}

This work is licensed under a Creative Commons Attribution-Non Commercial 4.0 International License subject to proper citation to the publication source of the work.

Disclaimer: The scholarly papers as reviewed and published by the Institute of Research Advances (IRA) are the views and opinions of their respective authors and are not the views or opinions of the IRA. The IRA disclaims of any harm or loss caused due to the published content to any party. 


\begin{abstract}
The study explores the worker's perception with respect to their compensation structure. The current study tries to explore the various dimensions associated with the compensation structure and other job related variables and personal variables. This empirical study tries to probe the relationship between pay satisfaction and the level of motivation exhibited by workmen in manufacturing industries. Similarly the role played by personal variables such as age, tenure on the job, and their association with pay satisfaction is also undertaken. The study is carried out in North Karnataka in cities like Belgaum, Hubli, Dharwad, Bijapur, Bagalkot, Gadag \& Gulbarga. 384 contractual workmen across different manufacturing organizations were surveyed to find out the relationship between the various dimensions. The collected data was subjected to chi-square analysis and independent $t$ test. The analysis revealed that there is a strong association between workmen age, nature of employment, motivational levels and their compensation structure. But, it was found out that there was no relationship between tenure on the job and pay satisfaction.
\end{abstract}

Keywords: Workmen, Pay Satisfaction \& Manufacturing Industries, independent t test.

\title{
1. Introduction:
}

Satisfied employees are a great source of strength for any organization across the world. Keeping employees satisfied with respect to their job is perhaps the biggest challenges to any organization. This is more so if the employees belong to the workmen category. Satisfaction is the positive feeling a person tends to carry with his job. The underlying reason to strive to keep employees satisfied with their job is that they tend to be happy and happy employees more often than not turn out to be the most productive employees. The bottom line of the organization is directly impacted by the productivity and efficiency of its employees and systems.

The ever changing needs and aspirations of human beings has always been mammoth challenge for human resource managers across the world. Motivated employees are the vital element in the very survival of any organization.

Workers, who are happy, not only contribute to the welfare of the organization but also tend to exhibit commitment to the organization. The other difficulty for human resource managers is retaining quality workers. When a workmen is in a state of harmony with his job, he commits herself or himself to the organization and helps managers in addressing the issue of attrition. There are several underlying factors or dimensions which contribute to the satisfaction of the employees and one important aspect is the compensation.

Compensation is the reward given for the service rendered by the employer to the employee. Compensation generally has both fixed and variable component. Compensation may be in the form of both monetary and non monetary reward.

Salary is designed to meet several needs of human beings such as basic physiological needs, security needs, social needs and self esteem needs. The common tendency among workmen is that they lay a high importance on the fixed component which is called as the base pay. The other issue with compensation is that the employees tend to compare theirs with the predecessors and their peers.

\section{Review of Literature}

Green and Baron (1997) observe compensation satisfaction is a result of individual's evaluation of multitude of factors.

Frey and Feld (2002) revealed in their research that pay satisfaction is the most important factor for success of an organization. Satisfaction is the state of happiness derived by an individual with respect to different dimensions. 
Cowin's (2002) in his research found out that compensation was a important determinator in the retention of nurses if they realized disparity, they would be dissatisfaction leading to quitting job. Motivation is positively associated with pay and job satisfaction (2004).

Yang, Miao, Zhu, Liu \& Wu (2008) revealed in their study that compensation and satisfaction had a strong relationship between each other. Richardson, W., Kirchenheim \& Richardson, C (2006) studied the relationship between salary satisfaction and other dimension of job. Salary satisfaction had a positive correlation with the job satisfaction. Workmen tend to attach a great deal of importance to significance to fairness of the compensation structure. They always compare their salary structure with the average market salary structure. Turnover intention surfaces as a result of the workmen's knowledge that their salary is less in comparison to the average salary structure in other organizations.

Taylor and Vest (2002) found out in their research, pay is an important aspect of job for a employee and has a direct impact on the motivational levels of the employees.

\section{Research Methodology}

Research Design; A descriptive research design has been adopted for the present study. The research has been carried out in districts of North Karnataka specifically Belgaum, Bagalkot, Dharwad, Bijapur, Gulbarga \& Gadag. Since the population is a finite population, we have adopted Yamane formula to determine the size of the sample. The Krejice \& Morgan table indicates a sample size of 384 respondents for a population more than 1 lakh. Stratified random sampling method has been employed to choose the desired number of samples. 192 contractual and 192 permanent workmen in various manufacturing industries in North Karnataka were chosen for the survey.

Both secondary and primary data would be used to arrive at the desired results. Independent T-test, chi-square method of statistical tools is employed to interpret the results. Secondary Data has been collected from Industrial reports published by Government of India. A mix of contractual and permanent workmen associated with manufacturing industries in the various districts of North Karnataka was the sampling unit for the survey.

\section{Objectives of the Study}

1. To study how workmen associated with manufacturing industries perceive their compensation structure.

2. To know whether age has any relationship with the pay satisfaction.

3. To understand the status of employment and its relationship with the satisfaction pay satisfaction.

4. To study the relationship between tenure on the job and pay satisfaction.

5. To explore the relationship between pay satisfaction and workmen motivation.

\section{Null Hypotheses:}

- Ho: There is no relationship between age and satisfaction with respect to compensation.

- $\mathrm{H}_{\mathrm{O}}$ : There is no relationship between work experience and satisfaction with respect to compensation.

- $\mathrm{H}_{\mathrm{O}}$ : There is no relationship between nature of employment and satisfaction with respect to compensation.

- $\mathrm{H}_{\mathrm{O}}$ : There is no relationship between level of motivation and pay satisfaction.

\section{Data Analysis:}

\section{a: Different dimensions as perceived by workmen with respect to their compensation}

Graph 1 reveals that most of the workmen believe that there is an acceptable level of transparency maintained by their individual organizations. Similarly graph -2 shows that large number of workers associated a strong linkage between their pay and performance. 
Organizations seem to have done reasonably well in creating awareness about the compensation policies governing individual workers as revealed in graph -3 . There seems to be a divided opinion when it comes to fairness of methods used for compensation according to graph-4. This divided opinion may be because of the fact that our sample is represented equally by contractual and full time workmen.

b. Chi-square analysis of age and satisfaction:

SPSS Table-1

AGE * SATISFACTION Crosstabulation

\begin{tabular}{|c|c|c|c|c|c|c|c|c|}
\hline & \multicolumn{5}{|c|}{ SATISFACTION } & \multirow[b]{2}{*}{ Total } \\
\hline & & & $\begin{array}{c}\text { STRONGL } \\
Y \\
\text { DISAGREE }\end{array}$ & DISAGREE & NEUTRAL & AGREE & $\begin{array}{l}\text { STRONGL } \\
\text { Y AGREE }\end{array}$ & \\
\hline \multirow[t]{6}{*}{$\overline{A G E}$} & $25-35$ & Count & 4 & 32 & 11 & 32 & 44 & 123 \\
\hline & & Expected Count & 26.6 & 25.0 & 20.8 & 26.3 & 24.3 & 123.0 \\
\hline & $35-45$ & Count & 24 & 38 & 46 & 15 & 20 & $14 \overline{3}$ \\
\hline & & Expected Count & 30.9 & 29.0 & 24.2 & 30.5 & 28.3 & 143.0 \\
\hline & $45-55$ & Count & 55 & 8 & 8 & 35 & 12 & 118 \\
\hline & & Expected Count & 25.5 & 24.0 & 20.0 & 25.2 & 23.4 & 118.0 \\
\hline \multirow[t]{2}{*}{ Total } & & Count & 83 & 78 & 65 & 82 & 76 & 384 \\
\hline & & Expected Count & 83.0 & 78.0 & 65.0 & 82.0 & 76.0 & 384.0 \\
\hline
\end{tabular}

SPSS Table -2

Chi-Square Tests

\begin{tabular}{|c|c|c|c|}
\hline & Value & $\mathrm{df}$ & $\begin{array}{l}\text { Asymp. } \\
\text { Sig. } \\
\text { (2-sided) }\end{array}$ \\
\hline Pearson Chi-Square & $138.439^{a}$ & 8 & .000 \\
\hline Likelihood Ratio & 142.860 & 8 & .000 \\
\hline $\begin{array}{l}\text { Linear-by-Linear } \\
\text { Association }\end{array}$ & 38.670 & 1 & .000 \\
\hline $\mathrm{N}$ of Valid Cases & 384 & & \\
\hline
\end{tabular}

a. 0 cells $(.0 \%)$ have expected count less than 5 . The minimum expected count is 19.97 .

As per table-2, The P value is less than 0.05 , therefore the null hypotheses is rejected at $5 \%$ level of significance. Hence it is concluded that there is a significant association between age of the workmen and level of satisfaction with respect to compensation. Table 1 reveals that younger workmen in the age bracket of 25 to 35 age-group tend to be more satisfied with their pay.

\section{c. Nature of Employment and its relation with pay satisfaction: \\ SPSS Table -3}

\section{Group Statistics}

\begin{tabular}{|ll|r|r|r|r|}
\hline & CATEGORY & $\mathrm{N}$ & Mean & \multicolumn{1}{c|}{$\begin{array}{c}\text { Std. } \\
\text { Deviation }\end{array}$} & $\begin{array}{c}\text { Std. Error } \\
\text { Mean }\end{array}$ \\
\hline SATISFACTION & Permanent Employees & 192 & 3.30 & 1.48 & .11 \\
& Contractual Employees & 192 & 2.65 & 1.33 & $9.57 \mathrm{E}-02.2$ \\
\hline
\end{tabular}


SPSS Table-4

Independent Samples Test

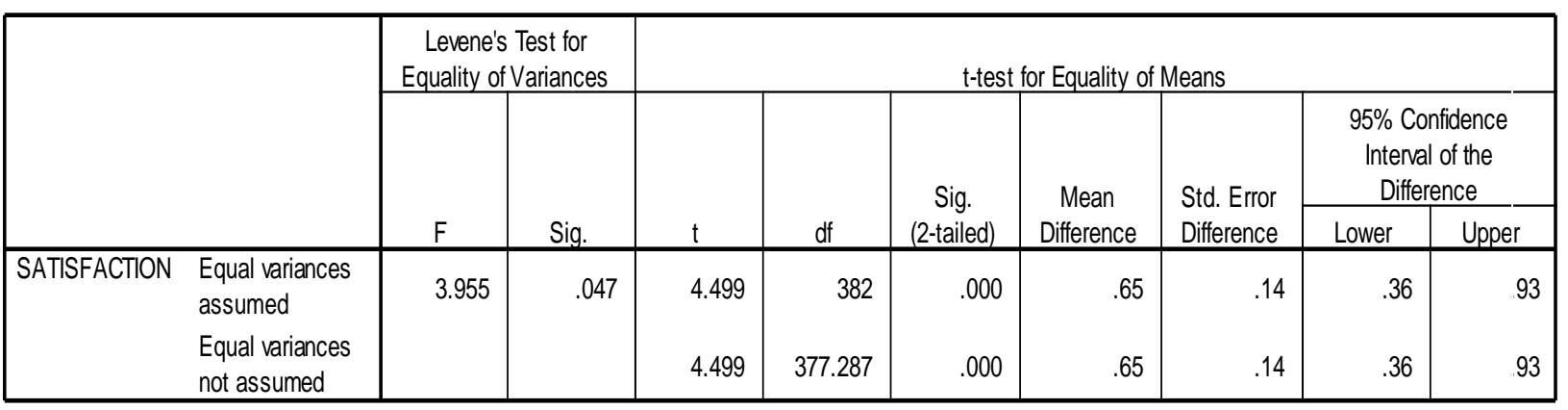

Independent $\mathrm{t}$ test results reveal that $\mathrm{p}$ value is less than .05 according to table no.4, leading to the interpretation that there is a strong linkage between nature of employment and satisfaction with respect to compensation.

\section{d. Relationship between work experience and pay satisfaction} SPSS Table-5

SATISFACTION * WORK EXPERIENCE Crosstabulation

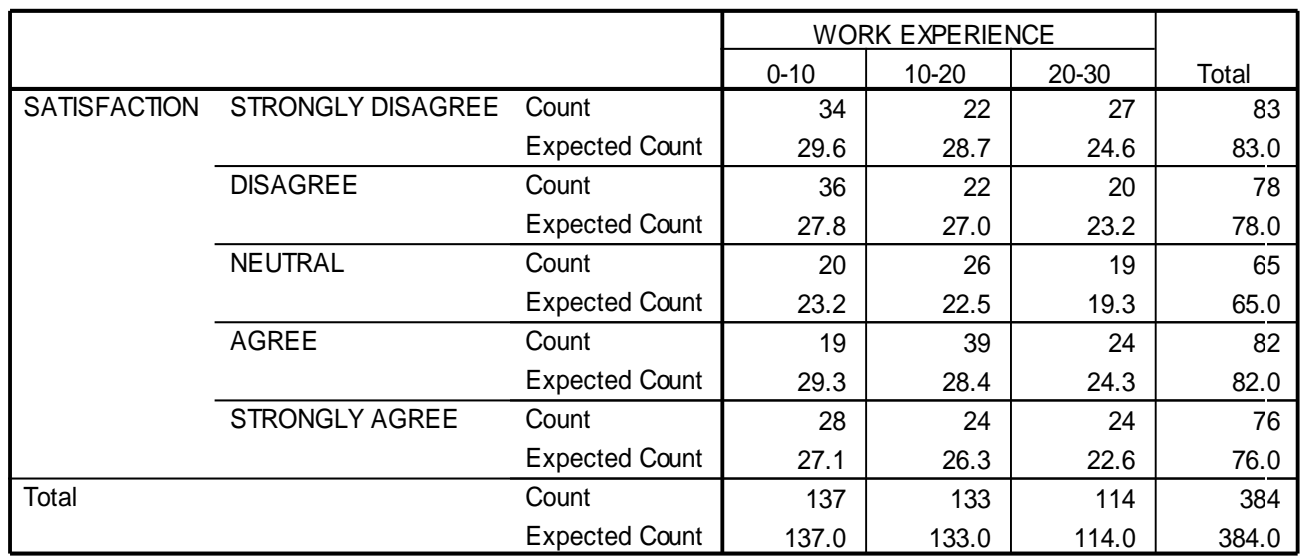

SPSS Table - 6

\section{Chi-Square Tests}

\begin{tabular}{|c|c|c|c|}
\hline & Value & df & $\begin{array}{l}\text { Asymp. } \\
\text { Sig. } \\
\text { (2-sided) }\end{array}$ \\
\hline Pearson Chi-Square & $14.941^{a}$ & 8 & .060 \\
\hline Likelihood Ratio & 15.013 & 8 & .059 \\
\hline $\begin{array}{l}\text { Linear-by-Linear } \\
\text { Association }\end{array}$ & 1.576 & 1 & .209 \\
\hline $\mathrm{N}$ of Valid Cases & 384 & & \\
\hline
\end{tabular}

a. 0 cells $(.0 \%)$ have expected count less than 5 . The minimum expected count is 19.59

The table no. 6 shows that $p$ value is .06 , which is more than .05 which indicates that tenure on the job has no relationship with pay satisfaction and hence the null hypothesis stands uncontested.

Relationship between motivation and pay satisfaction: 
SPSS Table-7

Motivation * SATISFACTION Crosstabulation

\begin{tabular}{|c|c|c|c|c|c|c|c|c|}
\hline & & & \multicolumn{5}{|c|}{ SATISFACTION } & \multirow[b]{2}{*}{ Total } \\
\hline & & & $\begin{array}{c}\text { STRONGL } \\
Y \\
\text { DISAGREE }\end{array}$ & DISAGREE & NEUTRAL & AGREE & $\begin{array}{l}\text { STRONGL } \\
\text { Y AGREE }\end{array}$ & \\
\hline \multirow[t]{8}{*}{ Motivation } & strongly disagree & Count & 0 & 18 & 4 & 0 & 8 & 30 \\
\hline & & Expected Count & 6.5 & 6.1 & 5.1 & 6.4 & 5.9 & 30.0 \\
\hline & disagree & Count & 32 & 16 & 0 & 23 & 8 & 79 \\
\hline & & Expected Count & 17.1 & 16.0 & 13.4 & 16.9 & 15.6 & 79.0 \\
\hline & agree & Count & 40 & 44 & 53 & 59 & 48 & $2 \cdot \overline{4}$ \\
\hline & & Expected Count & 52.7 & 49.6 & 41.3 & 52.1 & 48.3 & 244.0 \\
\hline & strongly agree & Count & 11 & 0 & 8 & 0 & 12 & 31 \\
\hline & & Expected Count & 6.7 & 6.3 & 5.2 & 6.6 & 6.1 & 31.0 \\
\hline \multirow[t]{2}{*}{ Total } & & Count & 83 & 78 & 65 & 82 & 76 & 3134 \\
\hline & & Expected Count & 83.0 & 78.0 & 65.0 & 82.0 & 76.0 & 384.0 \\
\hline
\end{tabular}

SPSS Table -8

Chi-Square Tests

\begin{tabular}{|l|r|r|r|}
\hline & Value & df & \multicolumn{1}{c|}{$\begin{array}{c}\text { Asymp. } \\
\text { Sig. } \\
\text { (2-sided) }\end{array}$} \\
\hline Pearson Chi-Square & $100.127^{\mathrm{a}}$ & 12 & .000 \\
Likelihood Ratio & 127.171 & 12 & .000 \\
Linear-by-Linear & 6.927 & 1 & .008 \\
Association & 384 & & \\
N of Valid Cases & & & \\
\hline
\end{tabular}

a. 0 cells $(.0 \%)$ have expected count less than 5 . The minimum expected count is 5.08 .

Table 8 indicates a $\mathrm{p}$ value less than .05 , which means that there is a relationship between motivational level of workmen and pay satisfaction.

\section{Conclusion:}

Perception of workmen about their work environment is a very crucial element in motivating the employees and propelling them to put in those extra efforts in their work. Perception of workmen about their work environment is largely dependent on the compensation that they receive. Several dimension of perceptions such as fairness of the compensation, transparency in the compensation structure, linkage to performance are considered to be important by the workmen working in the manufacturing industries.

It was found out that the workmen who are in the age bracket of 25 to 35 are found to be more content with their compensation which may be attributed to the fact that these workmen have less dependency and commitment. The research reiterated the old studies that employees who had satisfaction with compensation were found to be motivated. Workmen who had a secured job were found to be more satisfied with their compensation. Tenure on the job was found to be having no relationship with the pay satisfaction.

\section{References:}

[1] Frey, B.S., \& Feld, L. P. (2002). Deterrence and morale in taxation: An empirical analysis, working paper no. 760 .

[2] Carolyn Stringer, Jeni Didham, Paul Theivananthampillai, (2011) "Motivation, pay satisfaction, and job satisfaction of front-line employees", Qualitative Research in Accounting \& Management, Vol. 8 Issue: 2, pp.161-179. 
[3]Yang, H., Miao, D., Zhu, X., Sun, Y., Liu, X. \& Wu, S. 2008, "The influence of a pay increase on job satisfaction: A study with the Chinese army', Social Behaviour and Personality, 36(10): 13331340.

[4] Richardson, W., Kirchenheim \& Richardson, C (2006) Teachers and Their International Relocation: The Effect of Self-Esteem and Pay Satisfaction on Adjustment and Outcome Variables. International Education Journal, 7(7), 883-894.

[5] Hung-Wen Lee and Mei-Chun Lin (2014) "A study of salary satisfaction and job enthusiasm mediating effects of psychological contract" Vol. 24, Issue 24, July, 2014 page 1577-1583.

[6] Taylor and Vest (2002) Taylor, G. S. and Vest, M. J. (1992) "Pay Comparisons and Satisfaction among Public Sector Employees", Public Personnel Management, Vol. 21, pp 445-54.

[7] Green C. N., Baron G.A. (1977) "The Satisfaction-Performance Controversy" in Organizational Design, Development and Behaviour Ed. Karl O. Magnusen. Texas: Scott, Foresman and Company, pp.166. 


\section{Graph-1}

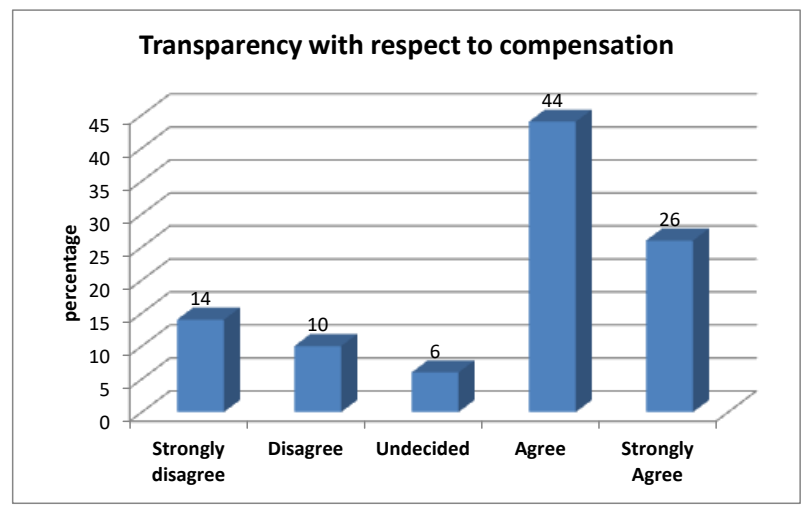

Based On Survey

\section{Graph-3}

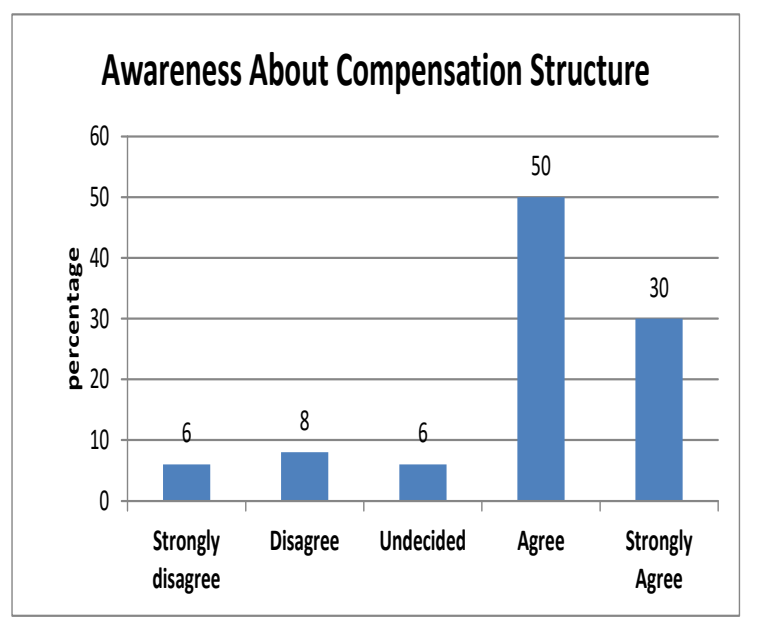

\section{Graph-2}

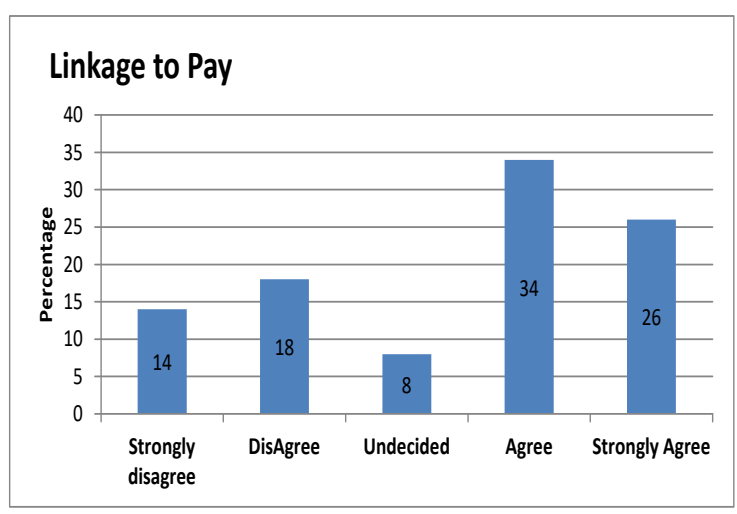

Based on Survey

\section{Graph-4}

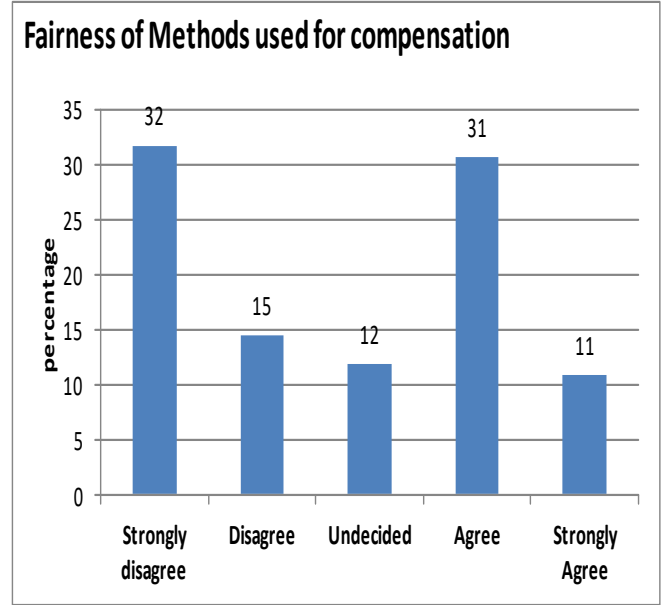

